\title{
Inhibiting Neddylation with MLN4924 Suppresses Growth and Delays Multicellular Development in Dictyostelium discoideum
}

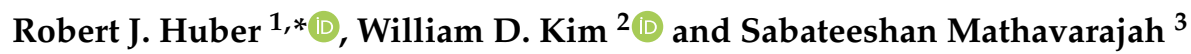 \\ 1 Department of Biology, Trent University, Peterborough, ON K9L 0G2, Canada \\ 2 Environmental and Life Sciences Graduate Program, Trent University, Peterborough, ON K9L 0G2, Canada; \\ williamkim@trentu.ca \\ 3 Department of Pathology, Dalhousie University, Halifax, NS B3H 4R2, Canada; smathavarajah@dal.ca \\ * Correspondence: roberthuber@trentu.ca; Tel.: +1-705-748-1011 (ext. 7316)
}

Citation: Huber, R.J.; Kim, W.D.;

Mathavarajah, S. Inhibiting

Neddylation with MLN4924

Suppresses Growth and Delays

Multicellular Development in

Dictyostelium discoideum. Biomolecules

2021, 11, 482. https://doi.org/

10.3390/biom11030482

Academic Editor: Dmitris Xirodimas

Received: 12 February 2021

Accepted: 19 March 2021

Published: 23 March 2021

Publisher's Note: MDPI stays neutral with regard to jurisdictional claims in published maps and institutional affiliations.

Copyright: () 2021 by the authors. Licensee MDPI, Basel, Switzerland. This article is an open access article distributed under the terms and conditions of the Creative Commons Attribution (CC BY) license (https:// creativecommons.org/licenses/by/ $4.0 /)$.

\begin{abstract}
Neddylation is a post-translational modification that is essential for a variety of cellular processes and is linked to many human diseases including cancer, neurodegeneration, and autoimmune disorders. Neddylation involves the conjugation of the ubiquitin-like modifier neural precursor cell expressed developmentally downregulated protein 8 (NEDD8) to target proteins, and has been studied extensively in various eukaryotes including fungi, plants, and metazoans. Here, we examine the biological processes influenced by neddylation in the social amoeba, Dictyostelium discoideum, using a well-established inhibitor of neddylation, MLN4924 (pevonedistat). NEDD8, and the target of MLN4924 inhibition, NEDD8-activating enzyme E1 (NAE1), are highly conserved in D. discoideum (Nedd8 and Nae1, respectively). Treatment of D. discoideum cells with MLN4924 increased the amount of free Nedd8, suggesting that MLN4924 inhibited neddylation. During growth, MLN4924 suppressed cell proliferation and folic acid-mediated chemotaxis. During multicellular development, MLN4924 inhibited cyclic adenosine monophosphate (cAMP)-mediated chemotaxis, delayed aggregation, and suppressed fruiting body formation. Together, these findings indicate that neddylation plays an important role in regulating cellular and developmental events during the $D$. discoideum life cycle and that this organism can be used as a model system to better understand the essential roles of neddylation in eukaryotes, and consequently, its involvement in human disease.
\end{abstract}

Keywords: neddylation; NEDD8; Dictyostelium discoideum; social amoeba; MLN4924; post-translational modification; growth; chemotaxis; development

\section{Introduction}

Ubiquitin, or ubiquitin-like modifiers such as neural precursor cell expressed developmentally downregulated protein 8 (NEDD8), target both proteins and lipids to control their degradation, subcellular localization, macromolecular interactions, and enzymatic activity [1,2]. NEDD8 is conjugated to a target protein at a C-terminal lysine through a process known as neddylation. Neddylation was first observed in the Saccharomycescerevisiae Skp1-Cullin-F-box (SCF) complex, where cullin-1 was found conjugated to Rub1 (ortholog of NEDD8) [3,4]. Cullin proteins, which are components of the cullin-RING ligase (CRL) superfamily (the SCF complex is a part of this superfamily), are one of the main targets of neddylation in eukaryotic cells [5]. They serve as scaffolds for multi-subunit ubiquitin ligases that target proteins for ubiquitination [6]. The assembly of CRL complexes is modulated by cullin-associated and neddylation dissociated 1 (CAND1), which binds and sequesters cullin proteins to prevent CRL assembly $[7,8]$. The neddylation of cullin proteins causes the displacement of CAND1, thus facilitating CRL assembly [9]. While cullin proteins are the most well-studied targets of neddylation, non-cullin targets of neddylation have also been reported in a variety of organisms, including Schizosaccharomyces pombe and Arabidopsis thaliana [10-12]. 
Cycles of neddylation and de-neddylation work in tandem to facilitate the downstream regulation of target substrates (e.g., transcription factors, DNA repair proteins, growth factor receptors, etc.) in a dynamic and essential manner [13-17]. Consequently, abnormalities in neddylation are associated with a variety of human diseases including cancer, neurodegeneration, and autoimmune disorders [18-20]. In addition, the complete loss of neddylation is lethal in many eukaryotic organisms [4,21,22]. Although neddylation has been well-studied in a variety of organisms including parasitic protozoa, fungi, plants, animals, and humans, the pathway has not yet been explored in detail in amoebozoa such as Dictyostelium discoideum [23-27]. D. discoideum is a unikont that emerged at least 600 million years ago, prior to the fungi-animal split [28]. The life cycle of $D$. discoideum is comprised of both unicellular and multicellular phases [29]. Thus, it can be used to gather insight into how neddylation coordinates both unicellular (e.g., cell proliferation) and multicellular (e.g., tissue remodeling) processes in more complex eukaryotes, all in one organism. Once amoebae are starved, they aggregate via chemotaxis towards cyclic adenosine monophosphate (cAMP) to form a multicellular mound $(0-10 \mathrm{~h})$. Following mound formation, cells differentiate into either pre-stalk ( $20 \%$ of population) or pre-spore $(\sim 80 \%$ of population) cells. These cell types then progress through the different developmental stages of the life cycle including the tipped mound (12-14 h), motile pseudoplasmodium (or slug) (16-18 h), culminant (20-22 h), and eventually, the fruiting body (24 h).

The $D$. discoideum genome encodes five proteins that contain a cullin homology domain (CulA-E encoded by culA-E) [30]. In terms of similarity, CulA is most similar to CUL1, CulB to CUL1 and CUL2, CulC to CUL3, CulD to CUL4A and CUL4B, and CulE to CUL1, CUL2, CUL5 (Table S1). Previous work showed that FLAG-tagged CulE is neddylated in slug-stage cells and that it interacts with orthologs of the mammalian neddylation machinery [31]. De-neddylation through the constitutive photomorphogenesis 9 (COP9) signalosome (CSN) has also been studied in D. discoideum and was revealed to play an important role in regulating cell proliferation [32]. The CSN is conserved across eukaryotes, from yeast to humans, and loss of CSN subunits results in aberrant phenotypes in all organisms studied to date [15,33-42]. Intriguingly, D. discoideum was identified as one of the earliest eukaryotes with a genome encoding an intact eight-subunit CSN [43]. These findings, coupled with the presence of an ortholog of human NEDD8 in D. discoideum (Nedd8), suggest that the neddylation pathway is conserved in D. discoideum.

In this study, we examine the role of the neddylation during the $D$. discoideum life cycle using the well-established neddylation inhibitor, MLN4924 (pevonedistat), which has been explored as its potential therapeutic for treating cancer, chronic liver diseases, and autoimmune diseases [15,44-49]. We identified previously unknown roles for neddylation in regulating $D$. discoideum growth, chemotaxis, aggregation, and fruiting body formation. We also establish $D$. discoideum as a model system for studying neddylation and highlight the potential of this organism to improve our understanding of the biological roles of neddylation and how this post-translational modification evolved in different eukaryotes. This work also identifies MLN4924 as an effective inhibitor for studying neddylation in D. discoideum and showcases the organism as a biomedical model system for informing work that evaluates the therapeutic potential of MLN4924.

\section{Materials and Methods}

\subsection{Cells, Media, Buffers, Chemicals, and Antibodies}

AX3 cells were obtained from the Dicty Stock Center [30]. Cells were grown and maintained on SM agar with Klebsiella aerogenes as well as axenically in HL5 medium at room temperature and $150 \mathrm{rpm}$ [50]. Cultures were supplemented with $100 \mu \mathrm{g} / \mathrm{mL}$ ampicillin and $300 \mu \mathrm{g} / \mathrm{mL}$ streptomycin sulfate to prevent bacterial growth. HL5 medium was purchased from Formedium (Hunstanton, Norfolk, United Kingdom). KK2 buffer was composed of $0.7 \mathrm{~g} / \mathrm{L} \mathrm{K}_{2} \mathrm{HPO}_{4}$ and $2.2 \mathrm{~g} / \mathrm{L} \mathrm{KH}_{2} \mathrm{PO}_{4}, \mathrm{pH}$ 6.5. MLN4924 (pevonedistat) (catalog number: 505477), folic acid (catalog number: F7876), and cAMP (catalog number: A9501) were purchased from Sigma-Aldrich Canada Corporation (Oakville, ON, Canada). 
MLN4924 was dissolved in dimethyl sulfoxide (DMSO), which served as the control treatment in all experiments. Rabbit monoclonal anti-NEDD8 (19E3) (catalog number: 2754), goat anti-rabbit IgG HRP (catalog number: 7074), and horse anti-mouse IgG HRP (catalog number: 7076) were purchased from New England Biolabs Limited (Whitby, ON, Canada). Mouse monoclonal anti- $\beta$-actin (C4) (catalog number: sc-47778) was purchased from Santa Cruz Biotechnology Incorporated (Dallas, TX, USA). Rabbit polyclonal antiCmfA was provided as a gift by Dr. Richard Gomer [51]. Rabbit polyclonal anti-CadA was generated and validated in a previous study [52]. Mouse monoclonal anti- $\alpha$-actinin (catalog number: 47-18-9) was purchased from the Developmental Studies Hybridoma Bank (University of Iowa, Iowa City, IA, USA) [53].

\subsection{Cell Proliferation Assay}

Cell proliferation was assessed as previously described [54]. Briefly, cells in the mid$\log$ phase of growth $(1-5 \times 106$ cells $/ \mathrm{mL})$ were diluted to $2 \times 10^{5}$ cells $/ \mathrm{mL}$ in fresh HL5 medium \pm MLN4924 (50 $\mu \mathrm{M}, 100 \mu \mathrm{M})$ and incubated at room temperature and $150 \mathrm{rpm}$. Cell concentrations were measured every $24 \mathrm{~h}$ over a 120 -h period using a hemocytometer. Statistical significance was assessed in GraphPad Prism 8 using two-way ANOVA followed by Bonferroni post-hoc analysis (GraphPad Software Incorporated, La Jolla, CA, USA). A $p$-value $<0.05$ was considered significant and $n$ represents the number of biological replicates that were analyzed.

\subsection{Radial Bioassay of Chemotaxis}

Chemotaxis towards folic acid and cAMP was assessed using a radial bioassay $[55,56]$. Briefly, cells were deposited into Petri dishes, submerged in HL5, and left to grow overnight. The following day, confluent cells were harvested, washed twice with KK2 buffer, and then plated $\left(0.25 \mu \mathrm{L}\right.$ of $1.5 \times 10^{8}$ cells $/ \mathrm{mL}$ suspension $)$ on $0.5 \%$ agar $/ \mathrm{KK} 2 \pm$ folic acid $(50 \mu \mathrm{M})$ or cAMP $(10 \mu \mathrm{M})$. MLN4924 $(50 \mu \mathrm{M})$ was added to dishes containing folic acid or cAMP to assess the effect of MLN4924 on folic acid-mediated and cAMP-mediated chemotaxis. Cell spots were imaged at 0 and $6 \mathrm{~h}$ using a Nikon Ts2R-FL inverted microscope equipped with a Nikon Digital Sight Qi2 monochrome camera (Nikon Canada Incorporated Instruments Division, Mississauga, Ontario, Canada). Images were viewed using NIS Elements Basic Research and analyzed using Fiji/ImageJ. The amount of migration was determined by measuring the diameters of cell spots at the 0 -h time point and subtracting those values from the diameters of cell spots after $6 \mathrm{~h}$. Statistical significance was assessed in GraphPad Prism 8 using the one sample $t$-test. A $p$-value $<0.05$ was considered significant and $n$ represents the number of biological replicates that were analyzed.

\subsection{Aggregation Assay}

Aggregation was assessed as previously described [57]. Briefly, cells were deposited into 6-well dishes, submerged in HL5, and left to grow overnight. The following day, confluent cells were washed twice with KK2 buffer and then submerged in KK2 buffer \pm MLN4924 $(1 \mu \mathrm{M}, 10 \mu \mathrm{M}, 50 \mu \mathrm{M})$. Cells were imaged using a Nikon Ts2R-FL inverted microscope equipped with a Nikon Digital Sight Qi2 monochrome camera. Images were viewed using NIS Elements Basic Research. To determine the effect of MLN4924 on the amounts of free Nedd8, CmfA, and CadA, cells were deposited into Petri dishes, submerged in HL5, and left to grow overnight. The following day, confluent cells were starved in KK2 buffer \pm MLN4924 (50 $\mu \mathrm{M})$ for $6 \mathrm{~h}$, after which time the conditioned buffer was harvested and cells were lysed with a buffer containing 0.5\% NP-40, $150 \mathrm{mM} \mathrm{NaCl}, 50 \mathrm{mM}$ Tris, $\mathrm{pH}$ 7.5, and a protease inhibitor tablet (i.e., NP-40 lysis buffer) (Fisher Scientific Company, Ottawa, Ontario, Canada). Samples were stored at $-80{ }^{\circ} \mathrm{C}$ for future use.

\subsection{Multicellular Development Assay}

To determine the amount of free Nedd8 in cells during the different stages of the $D$. discoideum life cycle, cells were deposited into Petri dishes, submerged in HL5, and left 
to grow overnight. The following day, confluent growth-phase cells were harvested and lysed with NP-40 lysis buffer. Samples were stored at $-80{ }^{\circ} \mathrm{C}$ for future use. Confluent cells were also harvested, washed twice with KK2 buffer, and deposited $\left(5 \times 10^{6}\right.$ total cells) on $0.5 \%$ agar $/ \mathrm{KK} 2$ contained within $100 \mathrm{~mm} \times 60 \mathrm{~mm}$ Petri dishes. The Petri dishes were placed on top of a moist paper towel and then covered with plastic wrap and aluminum foil to maintain a humid environment and ensure synchronous development. Cells were harvested every $4 \mathrm{~h}$ over a 24 -h period and then lysed with NP-40 lysis buffer. All samples were stored at $-80{ }^{\circ} \mathrm{C}$ for future use. To determine the effect of MLN4924 on multicellular development, cells were deposited into Petri dishes, submerged in HL5, and left to grow overnight. The following day, confluent cells were harvested and washed twice with KK2 buffer. Cells were then deposited ( $25 \mu \mathrm{L}$ of $2 \times 10^{7}$ cells $/ \mathrm{mL}$ suspension) onto $0.5 \%$ agar/KK2 \pm MLN4924 $(1 \mu \mathrm{M}, 10 \mu \mathrm{M}, 50 \mu \mathrm{M})$ contained within $60 \mathrm{~mm} \times 15 \mathrm{~mm}$ Petri dishes. All development dishes were imaged using a Leica EZ4W stereomicroscope equipped with an internal 5MP CMOS camera (Leica Microsystems Incorporated, Concord, Ontario, Canada). The statistical significance for the effect of MLN4924 on multicellular development was assessed in GraphPad Prism 8 using one-way ANOVA followed by Tukey's multiple comparison's test. A $p$-value $<0.05$ was considered significant and $n$ represents the number of biological replicates that were analyzed.

\subsection{SDS-PAGE and Western Blotting}

Protein quantification was performed using a Qubit 2.0 Fluorometer (Fisher Scientific Company, Ottawa, ON, Canada). Whole cell lysates and samples of conditioned buffer were resuspended in Laemmli sample buffer [58]. Samples were then heated at $95{ }^{\circ} \mathrm{C}$ for $5 \mathrm{~min}$. SDS-PAGE and Western blotting were performed using standard methods (2-h incubation at room temperature for primary and secondary antibodies in 5\% milk/TBST), except incubations with anti-NEDD8, which were performed overnight at $4{ }^{\circ} \mathrm{C}$ with rotation. The following primary and secondary antibodies were used: anti-NEDD8 (1:1000), anti- $\beta$-actin (1:2000), anti-CmfA (1:1000), anti-CadA (1:1000), anti- $\alpha$-actinin (1:1000), anti-rabbit IgG HRP (1:4000), and anti-mouse IgG HRP (1:4000). Immunoblots were digitally scanned using the ChemiDoc MP Imaging System (Bio-Rad Laboratories Limited, Mississauga, Ontario, Canada). Protein bands were quantified using Fiji/ImageJ and standardized against the levels of $\beta$-actin or $\alpha$-actinin. Statistical significance was assessed in GraphPad Prism 8 using the one-sample $t$-test. A $p$-value $<0.05$ was considered significant and $n$ represents the number of biological replicates that were analyzed.

\subsection{Bioinformatics}

Amino acid alignments were performed using the MUSCLE alignment tool available on MEGAX [59]. The alignment display was generated using the ESPRIPT 3.0 tool [60]. A structural homology model of $D$. discoideum Nae1 was generated using Phyre 2 and the 3DBR crystal structure template from the Research Collaboratory for Structural Bioinformatics Protein Data Bank [61,62].

\section{Results}

\subsection{The Putative Neddylation Pathway in D. discoideum Resembles the Metazoan Neddylation Pathway}

NEDD8 is the ubiquitin-like modifier that most closely resembles ubiquitin. Like ubiquitination, the conjugation of NEDD8 to target proteins (e.g., cullin proteins) follows an E1-E2-E3-like cascade [63]. D. discoideum Nedd8 (DDB0238041) is a 77-amino-acid protein that shares $82 \%$ exact identity (63/76 amino acids) and $92 \%$ positive similarity (70/76 amino acids) with the 81-amino-acid human NEDD8 protein (Q15843, Uniprot) (Figure 1A). D. discoideum Nedd8 also shares 55\% exact identity (43/77 amino acids) and $77 \%$ positive similarity (60/77 amino acids) with human polyubiquitin C (P0CG48, Uniprot) (Figure 1A). Akin to ubiquitin, NEDD8 is proteolytically processed to generate its mature form [64]. Once NEDD8 is translated into an inactive precursor, its short C- 
terminal amino acid extension is cleaved downstream of the RGG residues (Figure 1A). This C-terminal extension is only one-amino-acid long for $D$. discoideum Nedd8. In that sense, D. discoideum Nedd8 most closely resembles Nedd8 from Chlamydomonas reinhardtii, Saccharomyces cerevisae, and Caenorhabditis elegans.

Previous work on $D$. discoideum identified the proteins that interact with CulE, which included several orthologs of the mammalian neddylation machinery including the E3 ubiquitin protein ligase RBX1, CAND1, and subunits of the CSN [31]. The CSN, which is involved in de-neddylation, has also been characterized [32]. Using this information, we generated a putative model for neddylation/de-neddylation in D. discoideum (Figure 1B). The putative pathway includes orthologs of mammalian E1 (ubiquitin-activating enzyme E1C, Ube1C, DDB0238040; Nedd8-activating enzyme E1, Nae1, DDB0237981), E2 (ubiquitinconjugating enzyme E2 M, Ube2M, DDB0238042), and E3 (Rbx1, DDB0231276), as well as the NEDD8-processing enzymes ubiquitin carboxyl-terminal hydrolase isozyme L1 (UCHL1) (ubiquitin C-terminal hydrolase 1, Uch1, DDB0304593), ubiquitin carboxylterminal hydrolase isozyme L5 (UCHL5) (ubiquitin C-terminal hydrolase 2, Uch2, DDB0233 072), and sentrin-specific protease 8 (SENP8) (Senp8, DDB0304995) (Table S2). D. discoideum Uch1 also shows similarity to human ubiquitin carboxyl-terminal hydrolase isozyme L3 (UCHL3) (Table S2). However, unlike the mammalian pathway that utilizes two E2 proteins (UBE2M and UBE2F), the D. discoideum genome encodes a single E2 protein (Ube2M) that shares similarity to NEDD8-conjugating enzyme Ubc12 (UBE2M) (Table S2). The presence of NEDD8, NAE1, and cullin orthologs in D. discoideum, coupled with the neddylation of CulE, suggests that neddylation may play an important role during the $D$. discoideum life cycle.

MLN4924 is a synthetic drug that selectively inhibits NAE1 to prevent neddylation [44]. The inhibitor has been shown to bind NAE1 orthologs and inhibit neddylation in various organisms including yeast, zebrafish, and plants [65-67]. Homology modeling of D. discoideum Nae1 generated a structure that highly resembles human NAE1 (Phyre2 generated a structure with $100 \%$ confidence using human NAE1 as the template) (Figure 2A). At the amino acid level, the 520-amino-acid D. discoideum Nae1 protein shares $41 \%$ exact identity (219/524 amino acids) and 64\% positive similarity (336/524 amino acids) with the 534-amino-acid human NAE1 protein (Q13564, Uniprot) (data not shown). Overall, these findings suggest that the neddylation pathway is conserved from $D$. discoideum to mammals. 

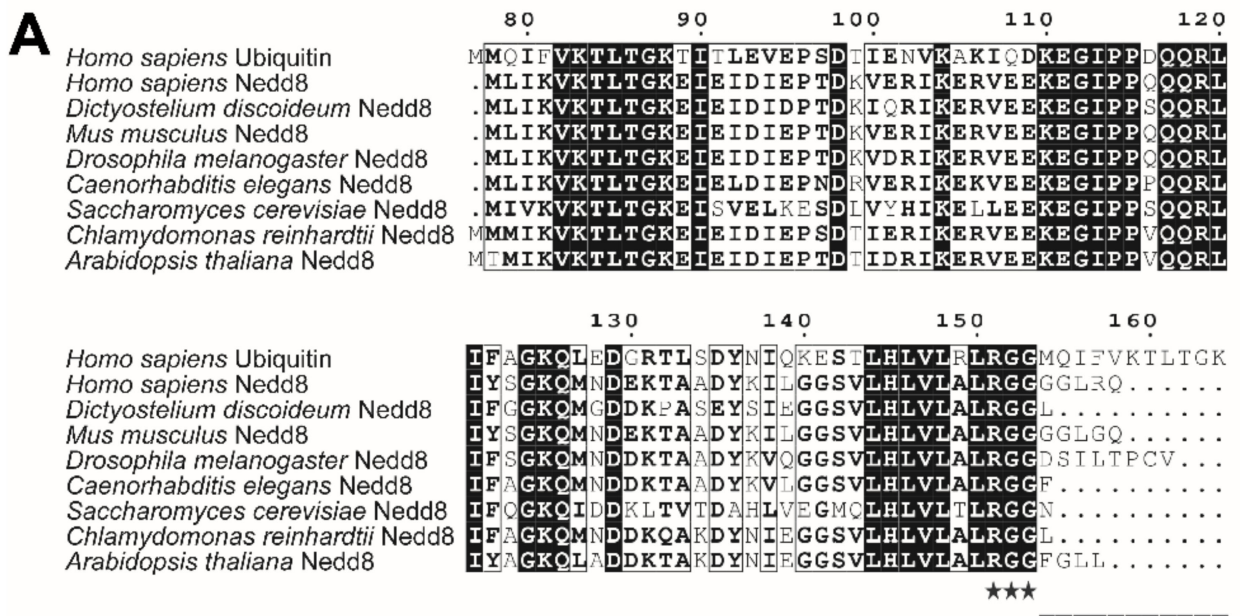

B
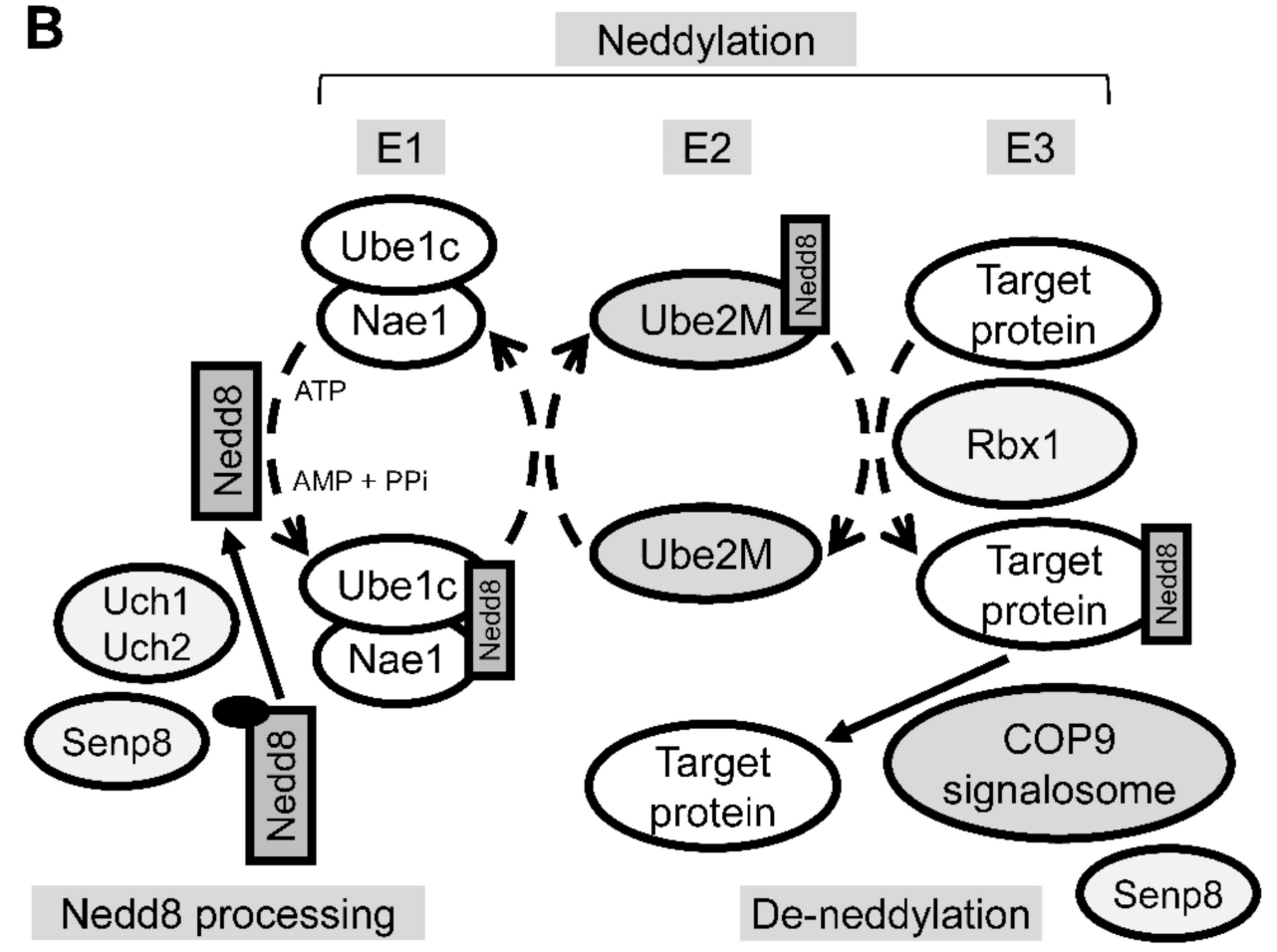

Figure 1. The putative neddylation pathway in Dictyostelium discoideum. (A) The D. discoideum neural precursor cell expressed developmentally downregulated protein 8 (Nedd8) is highly conserved and contains a single residue C-terminal extension. Alignments between human polyubiquitin C (P0CG48, Uniprot), human NEDD8 (Q15843, Uniprot), and NEDD8 orthologs in representative species (Mus musculus, P29595, Uniprot; Drosophila melanogaster, Q9VJ33, Uniprot; Caenorhabditis elegans, Q93725, Uniprot; Saccharomyces cerevisiae, Q03919, Uniprot; Dictyostelium discoideum, Q54XV3, Uniprot; Chlamydomonas reinhardtii, A8IZZ4, Uniprot; and Arabidopsis thaliana, Q9SHE7, Uniprot) were compiled and aligned using the MUSCLE alignment tool available on MEGAX. The sequence position number corresponds to the region of human ubiquitin that aligns to NEDD8. The RGG motif for NEDD8 conjugation is marked by stars. The C-terminal extension for NEDD8 and orthologous sequences is underlined. Sequence similarity is depicted in terms of \% equivalent for the colouring scheme. The alignment display was generated using the ESPRIPT 3.0 tool. (B) The proposed model showing how Nedd8 is conjugated to target proteins in D. discoideum. Nedd8 is translated as an inactive protein with a C-terminal extension (black oval) that is cleaved by ubiquitin C-terminal hydrolase 1 and 2 (Uch1 and Uch2, respectively) and sentrin-specific protease 8 (Senp8) to generate the mature Nedd8 protein, which is then transferred through an E1-E2-E3-like cascade to a target protein via ubiquitin-activating enzyme E1C (Ube1C), Nedd8-activating enzyme E1 (Nae1), ubiquitin-conjugating enzyme E2 M (Ube2M), and the E3 ubiquitin protein ligase Rbx1. De-neddylation is carried out by the constitutive photomorphogenesis 9 (COP9) signalosome. Senp8 also contributes to de-neddylation but is not essential to the process. 
A
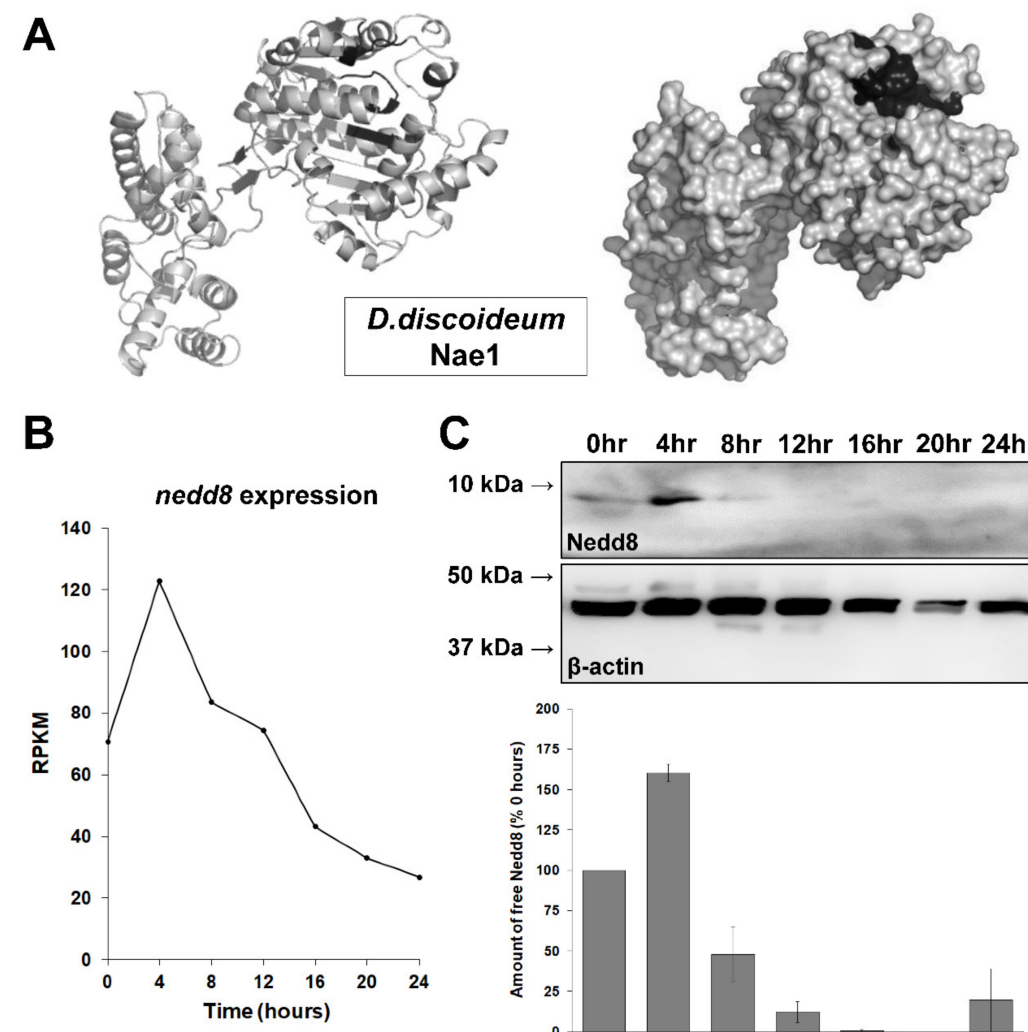

C $\quad 0 \mathrm{hr} \quad 4 \mathrm{hr} 8 \mathrm{hr} 12 \mathrm{hr} 16 \mathrm{hr} 20 \mathrm{hr} 24 \mathrm{hr}$
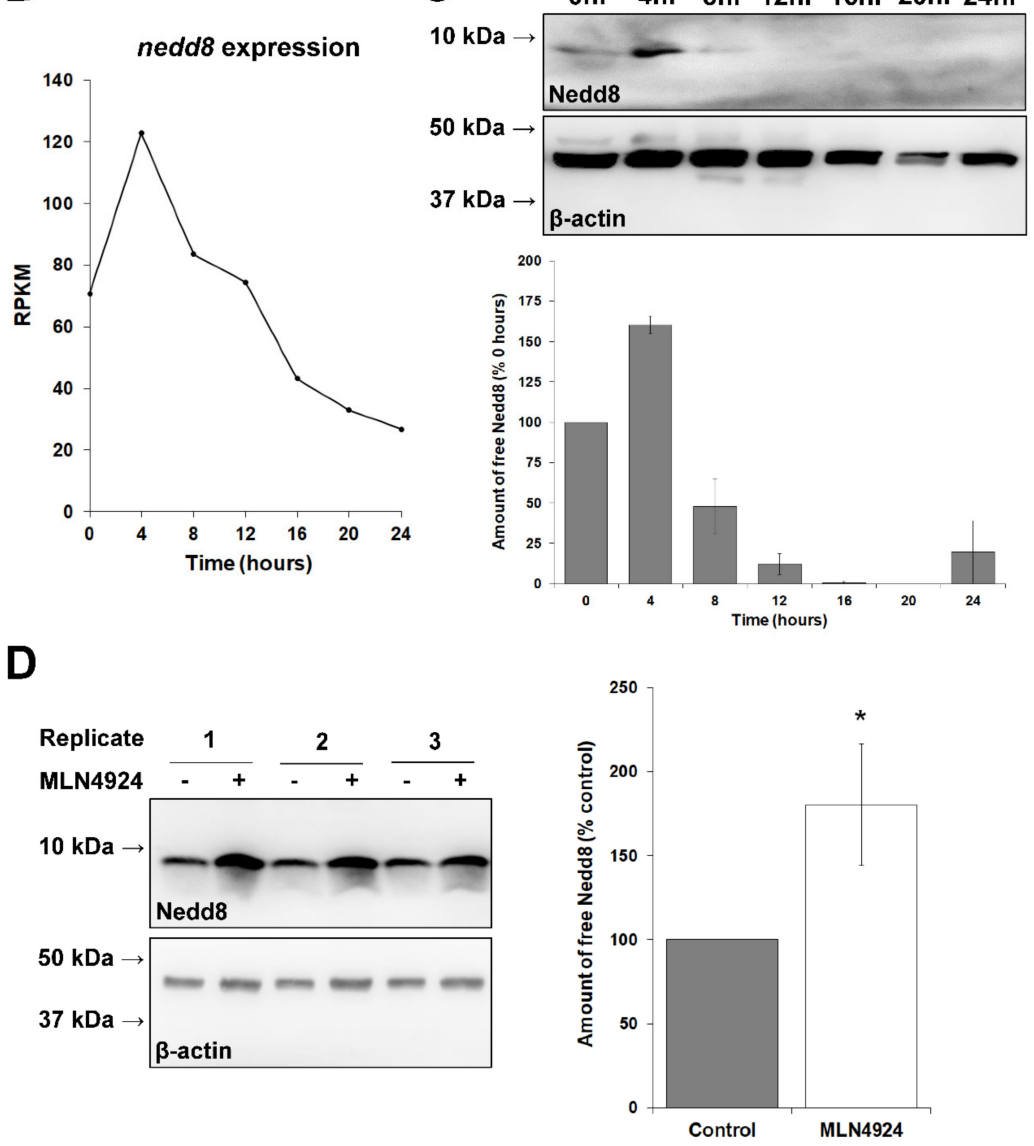

Figure 2. MLN4924 inhibits neddylation in D. discoideum. (A) Homology modeling of D. discoideum Nedd8-activating enzyme E1 (Nae1). The structure of Nae1 is highly conserved and predicted to bind MLN4924 (predicted binding pocket indicated in black). (B) Expression of nedd8 during D. discoideum growth and multicellular development. The $x$-axis represents the time of development: $0 \mathrm{~h}$ (growth), $4 \mathrm{~h}$ (chemotaxis), $8 \mathrm{~h}$ (aggregate formation), $12 \mathrm{~h}$ (mound), $16 \mathrm{~h}$ (slug), $20 \mathrm{~h}$ (culminant), $24 \mathrm{~h}$ (fruiting body). Reads per kilobase of transcript per million mapped reads (RPKM). RNA-seq data were obtained from dictyExpress and re-plotted using Microsoft Excel. (C) Amount of free Nedd8 in cells during the different stages of $D$. discoideum development. Whole cell lysates ( $20 \mu \mathrm{g}$ total protein) were separated by SDS-PAGE and analyzed by Western blotting with anti-NEDD8 and anti- $\beta$-actin (loading control). Western blots are representative of three biological replicates. Molecular weight markers (in $\mathrm{kDa}$ ) are shown to the left of each blot. Nedd8 protein bands were quantified and standardized against the amount of $\beta$-actin. Data are presented as the mean amount of free Nedd8 ( $\% 0 \mathrm{~h}) \pm$ SEM $(n=3)$. (D) Effect of MLN4924 on the amount of free Nedd8. Cells were starved in KK2 buffer in the presence and absence of MLN4924 (50 $\mu \mathrm{M}$, control: dimethyl sulfoxide) for $6 \mathrm{~h}$, after which time cells were lysed. Whole cell lysates (50 $\mu \mathrm{g}$ total protein) were separated by SDS-PAGE and analyzed by Western blotting with anti-NEDD8 and anti- $\beta$-actin (loading control). Three representative biological replicates are shown. Molecular weight markers (in kDa) are shown to the left of each blot. Nedd8 protein bands were quantified and standardized against the amount of $\beta$-actin. Data are presented as the mean amount of free Nedd8 (\% control) $\pm \operatorname{SEM}(n=19)$. Statistical significance was assessed using the one-sample $t$-test. $* p<0.05$ vs. control. 


\subsection{MLN4924 Inhibits Neddylation in D. discoideum}

The highly conserved structure of $D$. discoideum Nae1 suggests that MLN4924 has the capacity to bind Nae1 in D. discoideum and inhibit neddylation. To determine if MLN4924 inhibited neddylation in $D$. discoideum, we starved cells for $6 \mathrm{~h}$ in KK2 buffer in the presence and absence of MLN4924, since RNA-seq data show that nedd8 expression peaks during the early stages of multicellular development and then falls to its lowest levels during terminal differentiation (Figure 2B) [68]. We used a highly specific antibody directed against human NEDD8 to confirm this trend at the protein level (Figure 2C). Following incubation with MLN4924, cells were lysed. Proteins were then separated by SDS-PAGE and analyzed by Western blotting using anti-NEDD8 (Figure 2D). The amount of free Nedd8 was $80 \pm 36 \%$ higher in cells treated with MLN4924 compared to control cells, suggesting that neddylation was inhibited by MLN4924 (i.e., Nedd8 accumulated because it was not conjugated to target proteins). This finding indicated that MLN4924 could be used to study processes regulated by neddylation in D. discoideum.

\subsection{MLN4924 Inhibits Cell Proliferation and Folic Acid-Mediated Chemotaxis in D. discoideum}

In humans, proteins are de-neddylated by the CSN5 subunit of the CSN [69]. Loss of CSN5 ortholog in D. discoideum, csn5, severely impairs cell proliferation, suggesting that the cycling of neddylation and de-neddylation is important during growth [32]. Based on these observations, we tested the effect of MLN4924 in cultures of axenically growing $D$. discoideum cells. MLN4924 significantly reduced cell proliferation in a dose-dependent manner (Figure 3). Since growth-phase cells locate their food source by chemotactically responding to the folic acid that is secreted by bacteria, we next examined the effect of MLN4924 on folic acid-mediated chemotaxis. For this experiment, we used the well-established radial bioassay that assesses the migration of a population of $D$. discoideum cells in response to a self-generated gradient of chemoattractant [55]. In this assay, MLN4924 inhibited the migration of $D$. discoideum cells in response to folic acid by $23 \pm 4 \%$ (Figure $4 \mathrm{~A}, \mathrm{~B}$ ). Together, these findings suggest that neddylation plays a key role in regulating cell proliferation and folic acid-mediated chemotaxis during the growth-phase of the $D$. discoideum life cycle.

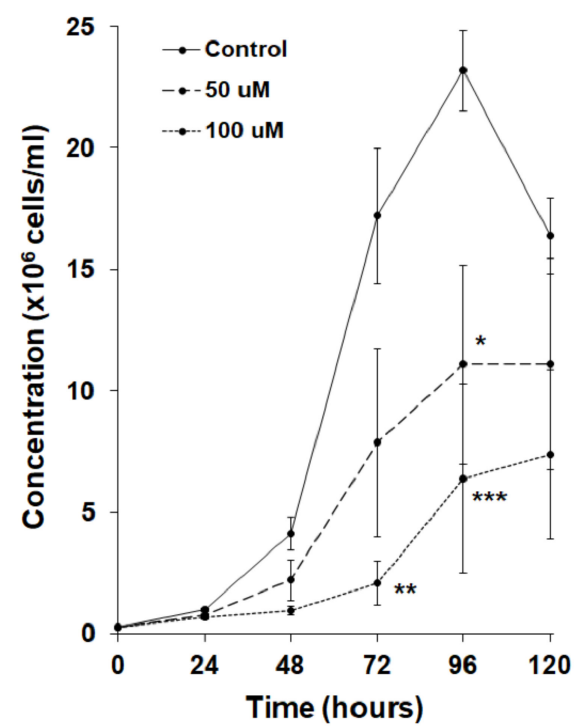

Figure 3. Effect of MLN4924 on cell proliferation. Cells were grown in HL5 medium in the presence and absence of MLN4924 ( $50 \mu \mathrm{M}, 100 \mu \mathrm{M}$, control: dimethyl sulfoxide) over a period of 5 days (120 h). Data presented as the mean concentration $\left(\times 10^{6}\right.$ cells $\left./ \mathrm{mL}\right) \pm \operatorname{SEM}(n \geq 4)$. Statistical significance was assessed using two-way ANOVA followed by Bonferroni post-hoc analysis. Two-way ANOVA revealed a significant effect of MLN4924 treatment on the growth curves $(p<0.0001) .{ }^{*} p<0.05$, ${ }^{* *} p<0.01$, and ${ }^{* * *} p<0.001$ vs. control at the indicated time points as determined from Bonferroni post-hoc analysis. 

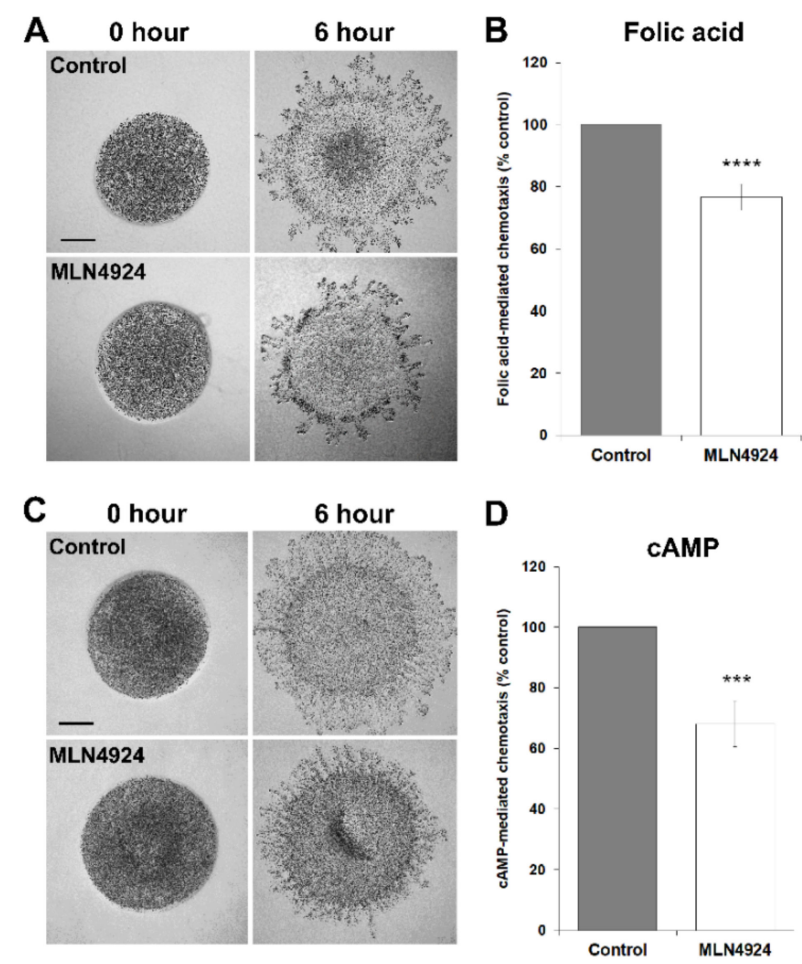

Figure 4. Effect of MLN4924 on folic acid-mediated and cyclic adenosine monophosphate (cAMP)mediated chemotaxis. (A) Cells were deposited onto $0.5 \%$ agar $/ \mathrm{KK} 2 /$ folic acid $(50 \mu \mathrm{M})$ in the presence and absence of MLN4924 (50 $\mu \mathrm{M}$, control: dimethyl sulfoxide). Images were taken once cells were deposited $(0 \mathrm{~h})$ and after $6 \mathrm{~h}$. Scale bar $=500 \mu \mathrm{m}$. (B) The amount of migration towards folic acid was quantified as detailed in the Section 2. Data are presented as the mean folic acid-mediated chemotaxis (\% control) \pm SEM $(n=13)$. (C) Cells were deposited onto $0.5 \%$ agar $/ \mathrm{KK} 2 / \mathrm{cAMP}(10 \mu \mathrm{M})$ in the presence and absence of MLN4924 (50 $\mu \mathrm{M}$, control: dimethyl sulfoxide). Images were taken once cells were deposited $(0 \mathrm{~h})$ and after $6 \mathrm{~h}$. Scale bar $=500 \mu \mathrm{m}$. (D) The amount of migration towards cAMP was quantified as detailed in the Section 2. Data presented as mean cAMP-mediated chemotaxis (\% control) $\pm \operatorname{SEM}(n=18)$. Statistical significance in $(\mathbf{B})$ and $(\mathbf{D})$ was assessed using the one-sample $t$-test. ${ }^{* *} p<0.001$ and ${ }^{* * *} p<0.0001$ vs. control.

\subsection{MLN4924 Treatment Inhibits cAMP-Mediated Chemotaxis and Delays the Aggregation of} D. discoideum Cells

CulA was previously shown to play a role in cAMP-mediated chemotaxis and cell aggregation [70]. Based on these observations, we assessed the effect of MLN4924 on cAMP-mediated chemotaxis, which drives multicellular aggregate formation during the early stages of multicellular development. In the radial bioassay, MLN4924 inhibited cAMPmediated chemotaxis by $32 \pm 8 \%$ compared to untreated cells (Figure $4 \mathrm{C}, \mathrm{D})$ ). When $D$. discoideum cells were starved in KK2 buffer with MLN4924, we observed a dose-dependent delay in aggregation (Figure 5). After $24 \mathrm{~h}$, mounds formed by cells treated with $50 \mu \mathrm{M}$ MLN4924 were amorphous in shape compared to control mounds with many cells not contributing to mound formation (Figure 5). To explore the mechanism underlying the delayed aggregation of MLN4924-treated cells, we examined the effect of MLN4924 on the intracellular and extracellular amounts of conditioned medium factor (CmfA) and calcium-dependent cell adhesion molecule A (CadA) after $6 \mathrm{~h}$ of starvation in KK2 buffer. CmfA is a $75-\mathrm{kDa}$ cell density-sensing secreted glycoprotein that enables starving cells to respond to pulses of cAMP [71]. CadA is a $\sim 25-\mathrm{kDa}$ protein that facilitates calciumdependent cell-to-cell interactions during aggregation and development [72]. Treatment with MLN4924 increased the intracellular and extracellular amounts of CmfA by $30 \pm 10 \%$ and $102 \pm 48 \%$, respectively, compared to untreated cells, suggesting that cells treated with MLN4924 attempt to compensate for the delayed aggregation by producing and 
secreting more CmfA (Figure 6). In contrast, there was no significant effect of MLN492 on the intracellular or extracellular amounts of CadA. Collectively, these results suggest an important role for neddylation in CAMP-mediated chemotaxis, aggregation, and mound formation during the early stages of $D$. discoideum development.

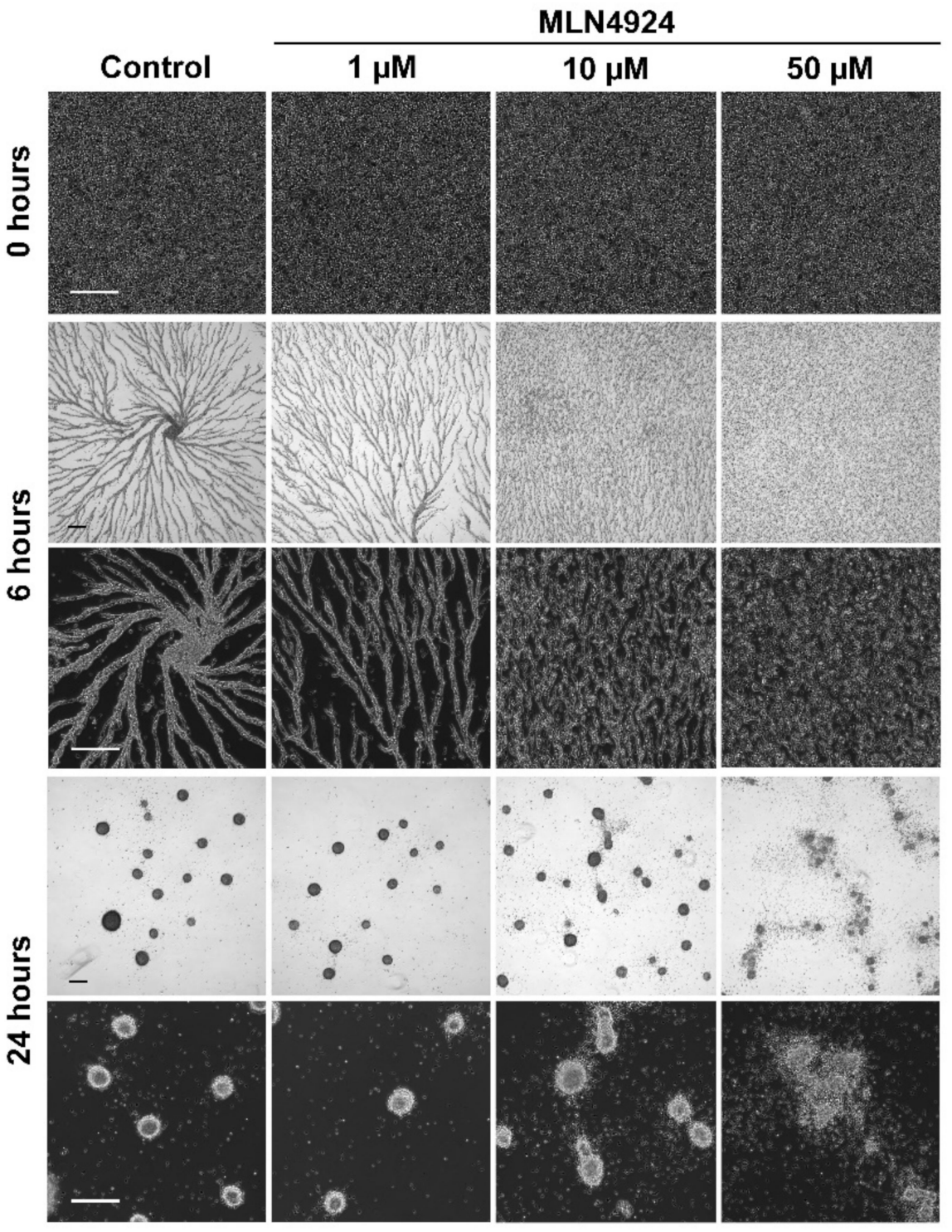

Figure 5. Effect of MLN4924 on aggregation. Cells were starved in KK2 buffer in the presence and absence of MLN4924 ( $1 \mu \mathrm{M}, 10 \mu \mathrm{M}, 50 \mu \mathrm{M}$, control: dimethyl sulfoxide). Cells were imaged at the indicated times. Scale bar $=250 \mu \mathrm{m}$. Images are representative of four independent experiments. 


\section{A Intracellular}
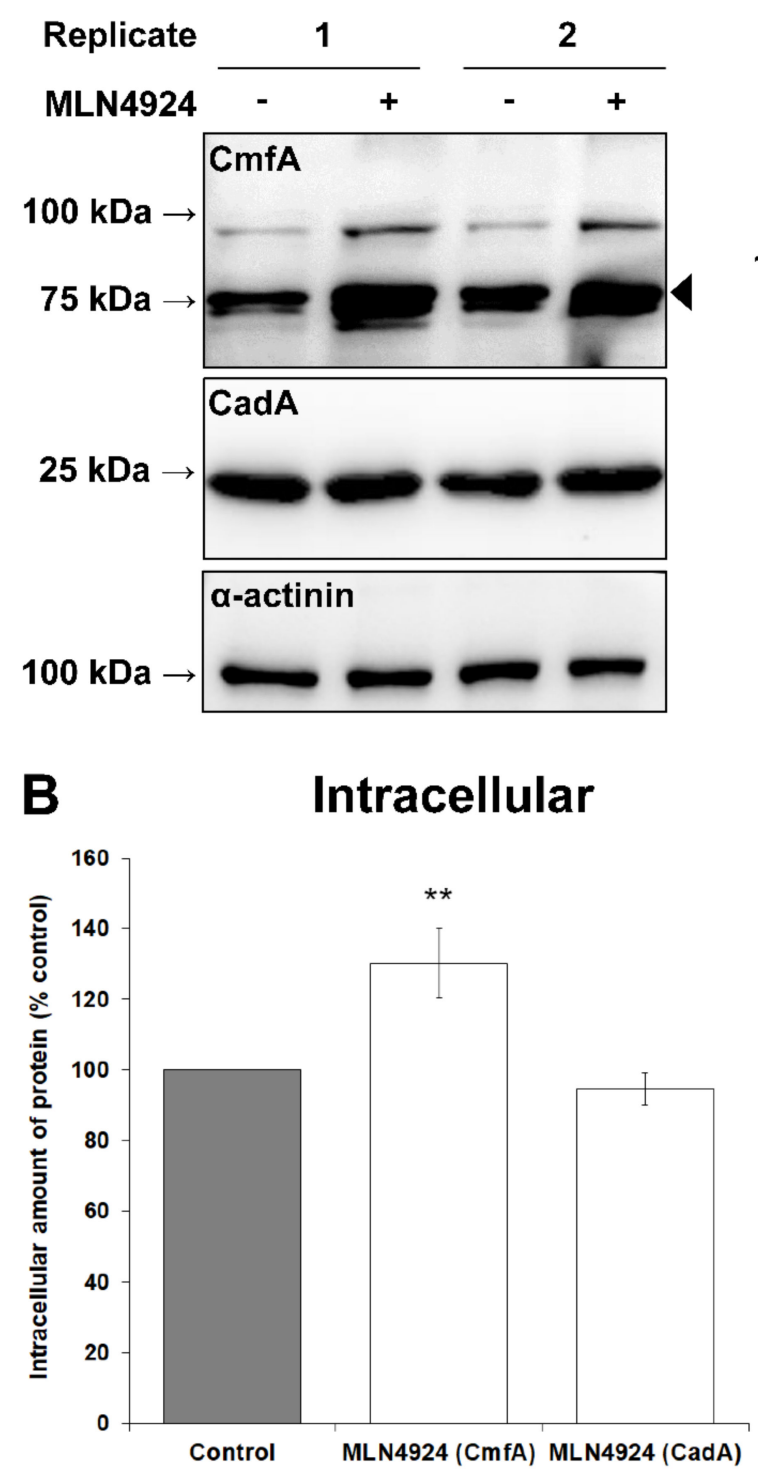
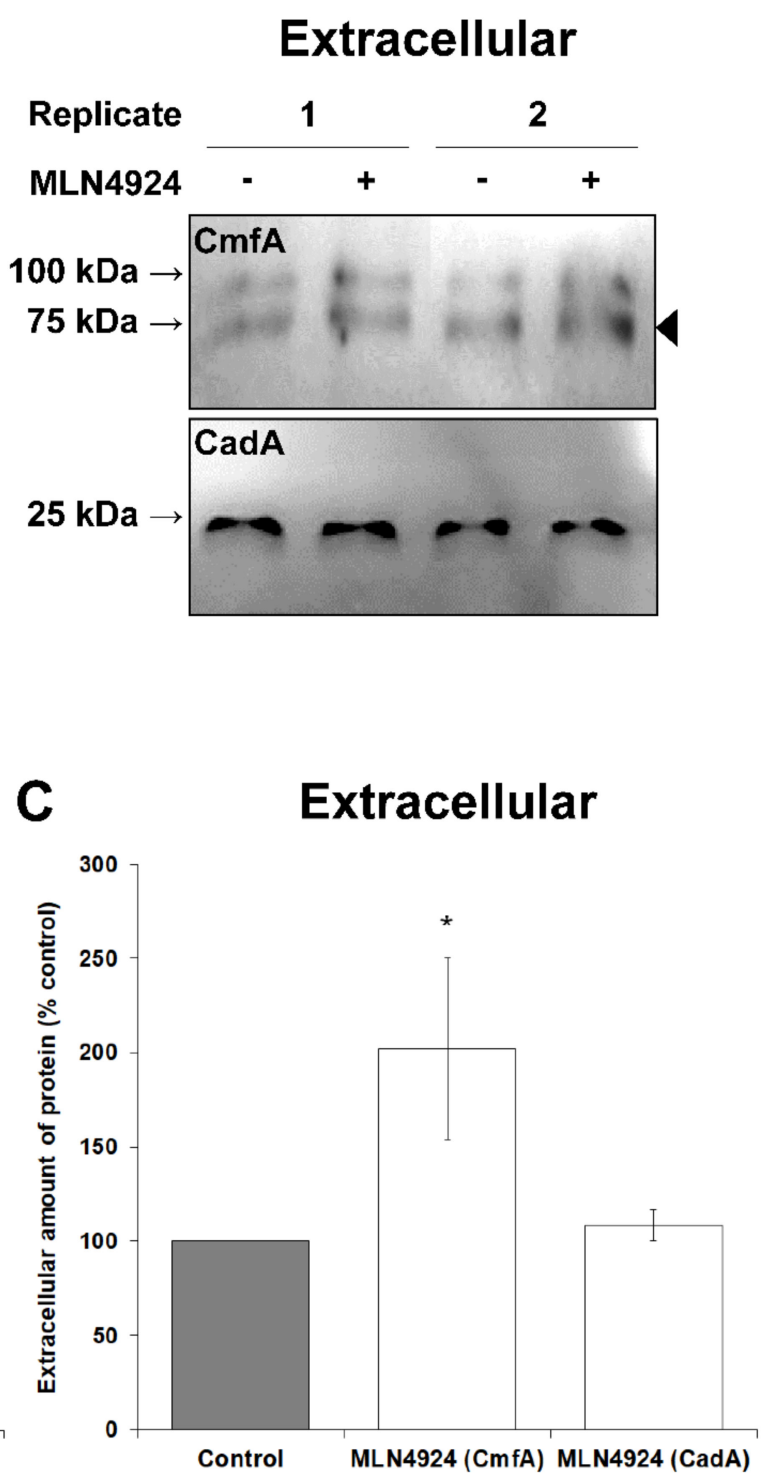

Figure 6. Effect of MLN4924 on the intracellular and extracellular amounts of conditioned media factor (CmfA) and calcium-dependent cell adhesion molecule A (CadA). (A) Cells were starved in KK2 buffer in the presence and absence of MLN4924 (50 $\mu \mathrm{M}$, control: dimethyl sulfoxide) for $6 \mathrm{~h}$, after which time the conditioned buffer was collected and cells were lysed. Whole cell lysates (WC, $50 \mu \mathrm{g}$ total protein) and equal volumes of conditioned buffer (CB, $15 \mu \mathrm{L})$ were separated by SDS-PAGE and analyzed by Western blotting with anti-CmfA, anti-CadA, and anti- $\alpha$-actinin (loading control). Two representative biological replicates are shown. Molecular weight markers (in $\mathrm{kDa}$ ) are shown to the left of each blot. The bands corresponding to CmfA are indicated with a black arrow to the right of each blot. (B) CmfA and CadA protein bands in whole cell lysates were quantified and standardized against the amount of $\alpha$-actinin. Data presented as mean intracellular amount of protein ( $\%$ control) $\pm \operatorname{SEM}(n=32)$. (C) CmfA and CadA protein bands in samples of conditioned buffer were quantified. Data presented as mean extracellular amount of protein (\% control) \pm SEM $(n=12)$. Statistical significance in (B) and (C) was assessed using the one-sample $t$-test. ${ }^{*} p<0.05$ and ${ }^{* *} p<0.01$ vs. control.

\subsection{MLN4924 Treatment Inhibits Fruiting Body Formation during D. discoideum Development}

CulA and CulB have previously been shown to regulate morphogenesis and cell type differentiation during $D$. discoideum development $[70,73]$. In addition, nae1, the target of MLN4924 inhibition, is upregulated in spores [74]. For these reasons, we developed cells on agar to examine the potential role of neddylation in the later stages of multicellular development. MLN4924 treatment significantly reduced the formation of multicellular structures 
by $\sim 70 \%$ and delayed the mid-to-late stages of development (e.g., pseudoplasmodium formation) (Figure 7A,B). After 24 h, MLN4924 dose-dependently inhibited fruiting body formation (Figure 7A,C). Development was severely impacted after treatment with $50 \mu \mathrm{M}$ MLN4924. Under these conditions, only $3 \pm 2 \%$ of multicellular structures developed into fruiting bodies after $24 \mathrm{~h}$, compared to $70 \pm 6 \%$ under control conditions (Figure 7A,C). Together, these findings suggest an important role for neddylation in the later stages of $D$. discoideum development.

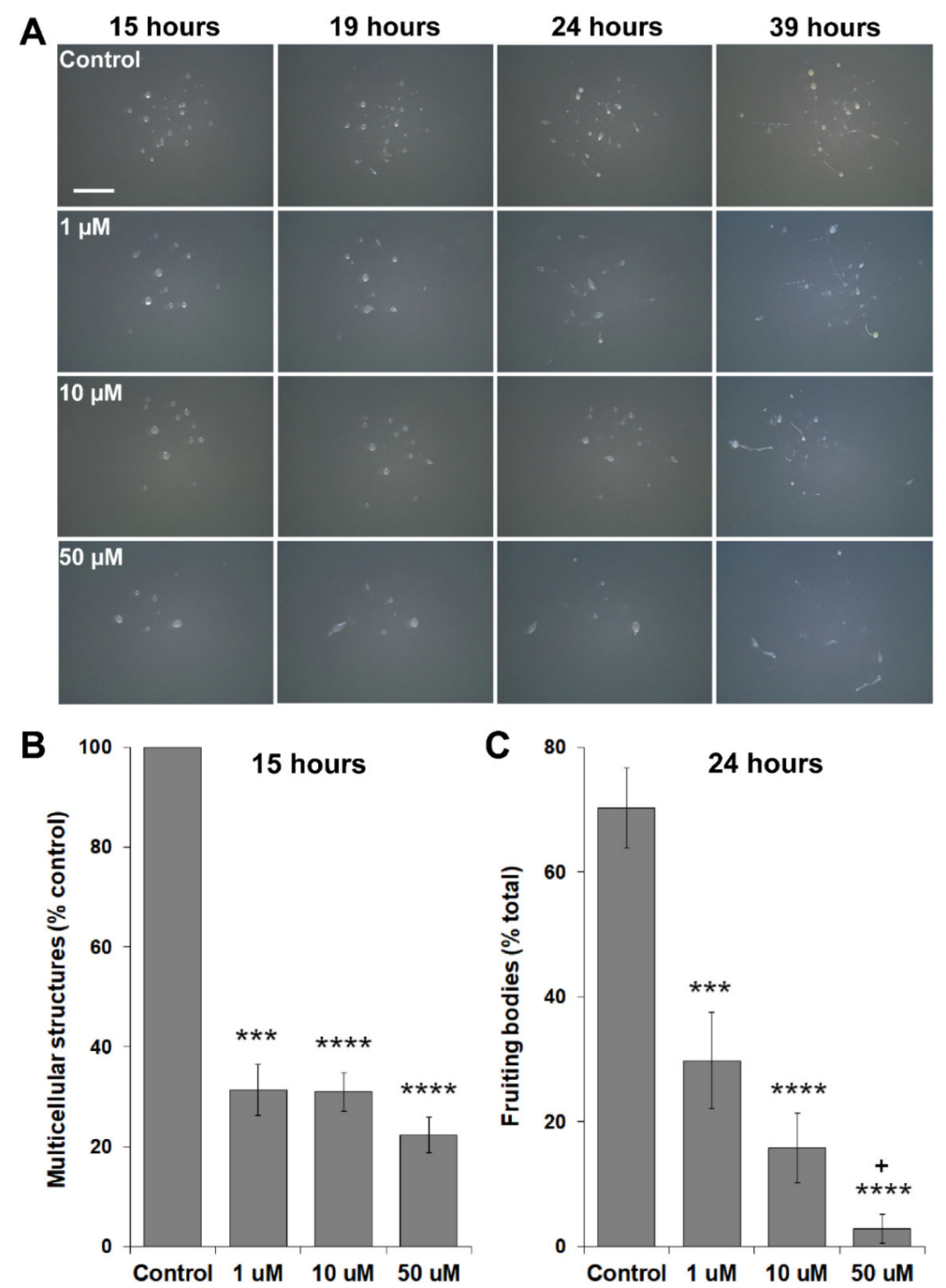

Figure 7. Effect of MLN4924 on multicellular development. (A) Cells were deposited onto $0.5 \%$ agar/KK2 in the presence and absence of MLN4924 $(1 \mu \mathrm{M}, 10 \mu \mathrm{M}, 50 \mu \mathrm{M}$, control: dimethyl sulfoxide). Dishes were imaged at the indicated times. Scale bar $=0.25 \mathrm{~cm}$. Images are representative of five independent experiments. (B) The number of multicellular structures observed after $15 \mathrm{~h}$ of development was quantified. Data are presented as the mean multicellular structures (\% control) $\pm \operatorname{SEM}(n \geq 5)$. Statistical significance was assessed using the one-sample $t$-test. ${ }^{* * *} p<0.001$ and ${ }^{* * * *} p<0.0001$ vs. control. (C) The percentage of fruiting bodies observed after $24 \mathrm{~h}$ of development was quantified. Data are presented as the mean fruiting bodies (\% total) \pm SEM $(n \geq 5)$. Statistical significance was assessed using one-way ANOVA followed by Tukey's multiple comparison's test. One-way ANOVA revealed a significant effect of MLN4924 treatment on fruiting body formation $(p<0.0001)$. ${ }^{* * *} p<0.001$ and ${ }^{* * * *} p<0.0001$ vs. control as determined by Tukey's multiple comparisons test. $+p<0.05$ vs. $1 \mu \mathrm{M}$ as determined by Tukey's multiple comparisons test. 


\section{Discussion}

In this study, we showed that neddylation is required for the growth and multicellular development of $D$. discoideum, which complements similar work in other organisms (e.g., parasitic protozoa, fungi, plants, animals, and humans) to better understand the biological roles of neddylation (Figure 8) [23-27]. The expression and amount of free Nedd8 peaked during the early stages of multicellular development, and then decreased dramatically during the mid-to-late stages. Treatment of cells with MLN4924 inhibited cell proliferation and folic acid-mediated chemotaxis during growth, and cAMP-mediated chemotaxis, aggregation, mound formation, and fruiting body formation during development. Combined, these data reveal the importance of neddylation during the $D$. discoideum life cycle, which enhances our understanding of neddylation in eukaryotes.

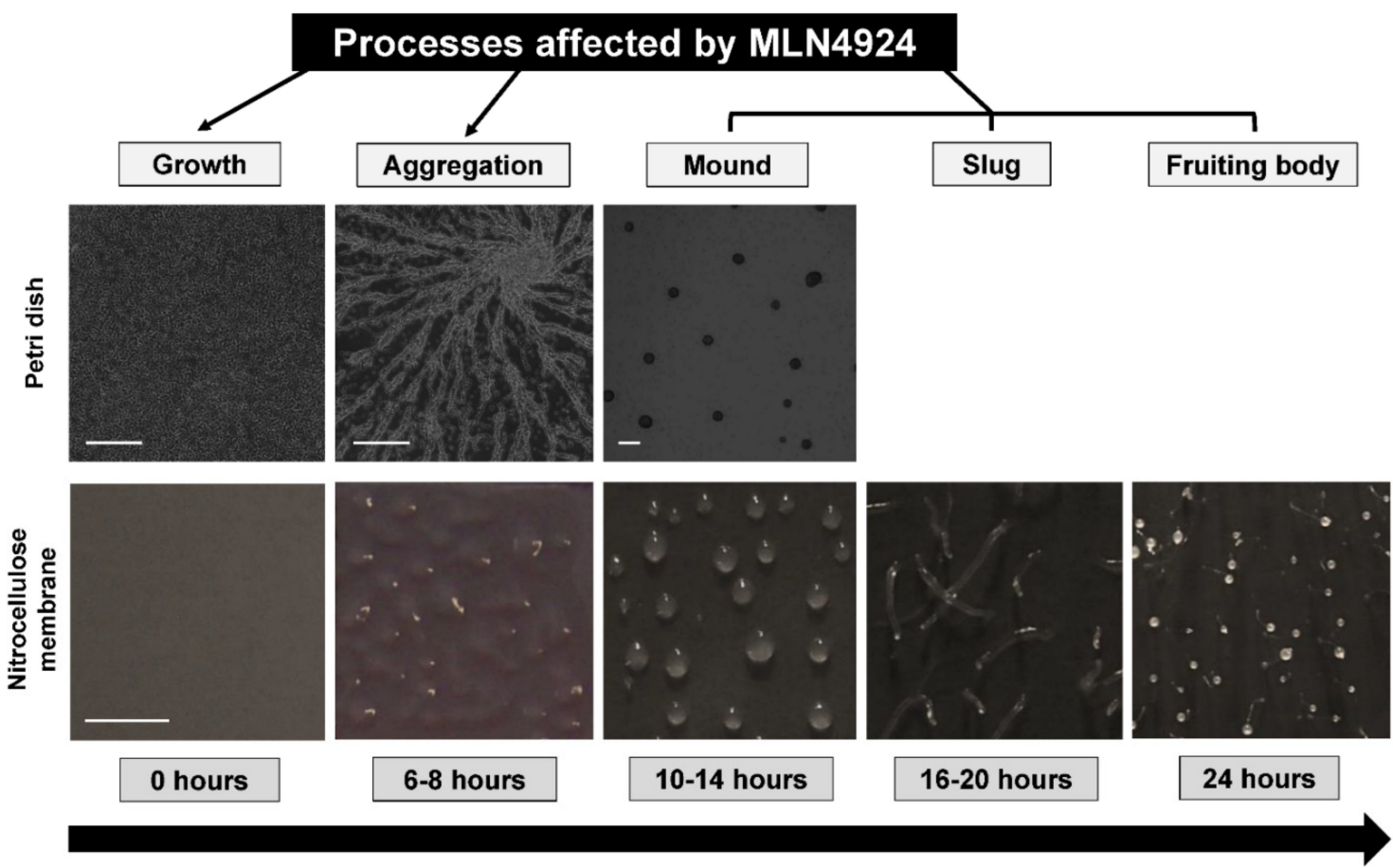

\section{The multicellular development of Dictyostelium discoideum}

Figure 8. Processes affected by MLN4924 during the D. discoideum life cycle. MLN4924 inhibits cell proliferation, chemotaxis, aggregation, and fruiting body formation, indicating that neddylation/de-neddylation regulates these cellular and developmental events during the $D$. discoideum life cycle. Images show the development of $D$. discoideum cells in two experimental environments commonly used in the laboratory: (1) cells adhered to Petri dishes and submerged in KK2 buffer and (2) cells deposited onto nitrocellulose membranes soaked in KK2 buffer. Note: Cells submerged in KK2 buffer do not develop past the mound stage. Scale bars (Petri dish) $=250 \mu \mathrm{m}$. Scale bar (nitrocellulose membrane) $=1000 \mu \mathrm{m}$.

Our bioinformatic analysis revealed several $D$. discoideum orthologs of human proteins associated with neddylation, suggesting that the neddylation pathway is conserved from D. discoideum to metazoans. This included orthologs of human NEDD8, NAE1, and others associated with the E1-E2-E3 cascade. Based on these findings, we examined the ability of the well-established neddylation inhibitor, MLN4924, to inhibit neddylation in D. discoideum. We observed increased levels of free Nedd8 in cells treated with MLN4924, suggesting that the chemical inhibited the conjugation of Nedd8 to target proteins.

Treatment of $D$. discioideum with MLN4924 significantly reduced cell proliferation and folic acid-mediated chemotaxis. Consistent with this finding, free Nedd8 was detected in growth-phase cells, and MLN4924 has been reported to inhibit the proliferation of a variety of cancer cell types [75-77]. In D. discoideum, previous work identified developmental roles for CulA and CulB, with no mention of growth-stage defects [70,73]. While these findings 
do not exclude the possibility that $c u l A^{-}$or $c u l B^{-}$cells display aberrant phenotypes during growth, they do suggest that there may be cullin-independent roles of neddylation during growth, which is consistent with observations in other organisms [10-12]. Growth defects have also been reported in $D$. discoideum cells lacking components of the de-neddylation machinery. In humans, de-neddylation of target proteins occurs via the CSN5 subunit of the CSN [69]. Loss of CSN5 ortholog in D. discoideum, csn5, severely impairs cell proliferation, suggesting that de-neddylation is important during growth [32]. A previous proteomics approach identified neddylated proteins in Trypanosoma brucei (a eukaryotic parasite that emerged prior to plants) and it included a long list of non-cullin proteins involved in a variety of cellular processes such as cell division and metabolism [78]. A number of these non-cullin proteins and their modification by neddylation may be a conserved posttranslational modification in $D$. discoideum. Therefore, future work should aim to identify non-cullin neddylated targets in $D$. discoideum to understand the full scope of neddylationregulated pathways in eukaryotes.

Multicellular development of $D$. discoideum begins with the aggregation of cells in response to the production and secretion of the chemoattractant cAMP. The SCF complex was previously shown to be essential for CAMP-mediated aggregation through its targeting of the cAMP phosphodiesterase RegA for ubiquitination and subsequent degradation [70]. Consistent with this finding, CulA binds RegA in vivo. Cells lacking culA accumulate RegA, which subsequently degrades cAMP to prevent chemotaxis and aggregation. In addition, the phenotypes of $c u l A^{-}$cells were linked to an inability of cells to properly activate the cAMP-dependent protein kinase A during multicellular development. These findings mirror the effects of MLN4924 on cAMP-mediated chemotaxis and aggregation observed in this study. They are also consistent with the detection of free Nedd8 during the early stages of D. discoideum development as well as multiple reports of MLN4924 inhibiting the migration of cancer cells [79-81]. Previous work in D. discoideum implicated another ubiquitin-like modification, SUMOylation, in the regulation of chemotaxis. D. discoideum mitogen-activated protein kinase kinase (MEK1) is a signaling kinase that regulates chemotaxis and was shown to be a target substrate for SUMOylation and ubiquitination [82]. SUMOylation of MEK1 occurred after chemoattractant stimulation. Similarly, there may be upstream signalling proteins involved in $D$. discoideum chemotaxis that are regulated by neddylation. Collectively, these findings suggest a role for ubiquitin-like post-translational modifications such as neddylation in regulating cell migration in eukaryotes, which is further supported by our observations of reduced folic acid-mediated chemotaxis in $D$. discoideum cells treated with MLN4924.

To gain insight into the pathways that may be affected by MLN4924 treatment in D. discoideum, we explored the effect of MLN4924 on the intracellular and extracellular amounts of the cell density-sensing glycoprotein, CmfA [71]. We observed increased amounts of intracellular and extracellular CmfA in cells treated with MLN4924, suggesting that cells may have attempted to compensate for the delayed aggregation by producing and secreting more CmfA. While these findings suggest that treatment with MLN4924 compromises cell-cell signaling during the early stages of development, we could not rule out the possibility that the increased amount of intracellular CmfA was due to impaired proteasome-mediated degradation. Thus, future work aimed at resolving the mechanism disrupted by MLN4924 in D. discoideum may consider examining the effect of the chemical on proteasome-mediated degradation. Interestingly, we observed no effect of MLN4924 on the intracellular or extracellular amounts of the calcium-dependent cell adhesion protein CadA, suggesting that MLN4924 may not affect cell-to-cell adhesion mechanisms [72].

Previous work linked the functions of CulA and CulB to morphogenesis and cell differentiation during $D$. discoideum development $[70,73]$. Spore formation does not occur in the absence of $c u l A$, and loss of $c u l B$ causes aberrant pre-stalk cell differentiation that ultimately affects fruiting body size. Similarly, when neddylation is inhibited by MLN4924, there is a significant reduction in the percentage of fruiting bodies that develop from multicellular aggregates. It is likely that neddylation inhibition prevents the required assembly 
of the CulA- and CulB-associated CRLs to facilitate normal differentiation. However, as previously mentioned, there may be other neddylated proteins in D. discoideum that are also involved in differentiation and are affected by MLN4924. For example, CarC, a cAMP receptor involved in cell differentiation was previously identified as an interactor of Csn5 [31]. Although it has yet to be shown, it is possible that CarC is neddylated, which could be a contributing factor to the reduced fruiting body formation we observed when cells were treated with MLN4924. Therefore, D. discoideum can be used as a model system to better understand how neddylation influences cell fate decisions and differentiation, which can improve our understanding of its role in human development.

\section{Conclusions}

This study demonstrates how D. discoideum can be used as a model system to better understand the unicellular and multicellular processes regulated by neddylation. Future work that identifies the targets of neddylation in $D$. discoideum may reveal non-cullin targets of neddylation that could inform research in other organisms to enhance our understanding of neddylation in all eukaryotes. In this paper, we showed a dose-dependent effect of MLN4924 on growth, aggregation, and multicellular development, which suggests the chemical is not toxic to cells and that it acts specifically on Nae1, as in other organisms. While we saw no evidence of cell death during treatment with MLN4924, we cannot rule out the possibility that MLN4924 is toxic at higher concentrations. Finally, this work identifies MLN4924 as an effective inhibitor of neddylation in D. discoideum and highlights the potential of $D$. discoideum to serve as a unique biomedical model system for examining the therapeutic potential of MLN4924.

Supplementary Materials: The following are available online at https:/ / www.mdpi.com/2218-273 X/11/3/482/s1, Table S1. D. discoideum proteins orthologous to human cullin proteins; Table S2. D. discoideum proteins orthologous to human proteins involved in the neddylation pathway.

Author Contributions: Conceptualization, S.M. and R.J.H.; Methodology, S.M. and R.J.H.; Homology modeling, S.M.; Investigation, R.J.H. and W.D.K.; Writing—original draft preparation, S.M. and R.J.H.; Writing-review and editing, R.J.H.; Supervision, R.J.H.; Project administration, R.J.H.; Funding acquisition, R.J.H. All authors have read and agreed to the published version of the manuscript.

Funding: This work was supported by the Natural Sciences and Engineering Research Council of Canada (Discovery Grant to R.J.H., RGPIN-2018-04855; Canada Graduate Scholarship Masters to W.D.K.). S.M. was supported by a Killam Pre-Doctoral Award, a Nova Scotia Graduate Scholarship, and the President's Award from Dalhousie University.

Institutional Review Board Statement: Not applicable.

Informed Consent Statement: Not applicable.

Data Availability Statement: Not applicable.

Acknowledgments: The authors would like to thank Richard Gomer (Texas A\&M University) for generously providing antibodies against conditioned medium factor (CmfA).

Conflicts of Interest: The authors declare no conflict of interest.

\begin{tabular}{|c|c|}
\hline \multicolumn{2}{|c|}{ Abbreviations } \\
\hline \multicolumn{2}{|c|}{ The following abbreviations are used in this manuscript: } \\
\hline CadA & calcium-dependent cell adhesion molecule A \\
\hline CAND1 & cullin-associated and neddylation dissociated 1 \\
\hline CmfA & conditioned medium factor \\
\hline COP9 & constitutive photomorphogenesis 9 \\
\hline CRL & cullin-RING ligase \\
\hline CSN & COP9 signalosome \\
\hline CUL & cullin \\
\hline
\end{tabular}




$\begin{array}{ll}\text { DMSO } & \text { dimethyl sulfoxide } \\ \text { NAE1 } & \text { NEDD8 activating enzyme E1 } \\ \text { NEDD8 } & \text { neural precursor cell expressed, developmentally downregulated protein } 8 \\ \text { RBX1 } & \text { E3 ubiquitin protein ligase } \\ \text { SCF } & \text { Skp1-Cullin-F-box } \\ \text { SENP8 } & \text { sentrin-specific protease } 8 \\ \text { Ube1C } & \text { ubiquitin-activating enzyme E1C } \\ \text { Ube2M } & \text { ubiquitin-conjugating enzyme E2 M } \\ \text { UBE2M } & \text { NEDD8-conjugating enzyme Ubc12 } \\ \text { Uch1 } & \text { ubiquitin C-terminal hydrolase 1 } \\ \text { Uch2 } & \text { ubiquitin C-terminal hydrolase 2 } \\ \text { UCHL1 } & \text { ubiquitin carboxyl-terminal hydrolase isozyme L1 } \\ \text { UCHL3 } & \text { ubiquitin carboxyl-terminal hydrolase isozyme L3 } \\ \text { UCHL5 } & \text { ubiquitin carboxyl-terminal hydrolase isozyme L5 }\end{array}$

\section{References}

1. Cappadocia, L.; Lima, C.D. Ubiquitin-like protein conjugation: Structures, chemistry, and mechanism. Chem. Rev. 2017, 118, 889-918. [CrossRef] [PubMed]

2. Vierstra, R.D. The expanding universe of ubiquitin and ubiquitin-like modifiers. Plant Physiol. 2012, 160, 2-14. [CrossRef] [PubMed]

3. Liakopoulos, D.; Doenges, G.; Matuschewski, K.; Jentsch, S. A novel protein modification pathway related to the ubiquitin system. EMBO J. 1998, 17, 2208-2214. [CrossRef]

4. Lammer, D.; Mathias, N.; Laplaza, J.M.; Jiang, W.; Liu, Y.; Callis, J.; Goebl, M.; Estelle, M. Modification of yeast Cdc53p by the ubiquitin-related protein Rub1p affects function of the SCFCdc4 complex. Genes Dev. 1998, 12, 914-926. [CrossRef]

5. Petroski, M.D.; Deshaies, R.J. Function and regulation of cullin-RING ubiquitin ligases. Nat. Rev. Mol. Cell Biol. 2005, 6, 9-20. [CrossRef] [PubMed]

6. Zimmerman, E.S.; Schulman, B.A.; Zheng, N. Structural assembly of cullin-RING ubiquitin ligase complexes. Curr. Opin. Struct. Biol. 2010, 20, 714-721. [CrossRef] [PubMed]

7. Zheng, J.; Yang, X.; Harrell, J.M.; Ryzhikov, S.; Shim, E.-H.; Lykke-Andersen, K.; Wei, N.; Sun, H.; Kobayashi, R.; Zhang, H. CAND1 Binds to unneddylated CUL1 and regulates the formation of SCF ubiquitin E3 ligase complex. Mol. Cell 2002, 10, 1519-1526. [CrossRef]

8. Dubiel, D.; Gierisch, M.E.; Huang, X.; Dubiel, W.; Naumann, M. CAND1-dependent control of cullin 1-RING Ub ligases is essential for adipogenesis. Biochim. Biophys. Acta BBA Mol. Cell Res. 2013, 1833, 1078-1084. [CrossRef]

9. Liu, J.; Furukawa, M.; Matsumoto, T.; Xiong, Y. NEDD8 modification of CUL1 dissociates p120CAND1, an inhibitor of CUL1-SKP1 binding and SCF ligases. Mol. Cell 2002, 10, 1511-1518. [CrossRef]

10. Girdwood, D.; Robertson, M.; Gordon, C. Constitutively active Cullin-RING-Ligases fail to rescue loss of NEDD8 conjugation in Schizosaccharomyces pombe. FEBS Lett. 2012, 586, 1522-1528. [CrossRef]

11. Mergner, J.; Heinzlmeir, S.; Kuster, B.; Schwechheimer, C. DENEDDYLASE1 Deconjugates NEDD8 from non-cullin protein substrates in Arabidopsis thaliana. Plant. Cell 2015, 27, 741-753. [CrossRef]

12. Enchev, R.I.; Schulman, B.A.; Peter, M. Protein neddylation: Beyond cullin-RING ligases. Nat. Rev. Mol. Cell Biol. 2014, 16, 30-44. [CrossRef]

13. Cope, G.A.; Deshaies, R.J. COP9 signalosome: A multifunctional regulator of SCF and other cullin-based ubiquitin ligases. Cell 2003, 114, 663-671. [CrossRef]

14. Bosu, D.R.; Kipreos, E.T. Cullin-RING ubiquitin ligases: Global regulation and activation cycles. Cell Div. 2008, 3, 1-13. [CrossRef] [PubMed]

15. Zemla, A.; Thomas, Y.; Kedziora, S.; Knebel, A.; Wood, N.T.; Rabut, G.; Kurz, T. CSN- and CAND1-dependent remodelling of the budding yeast SCF complex. Nat. Commun. 2013, 4, 1641. [CrossRef] [PubMed]

16. Chung, D.; Dellaire, G. The Role of the COP9 signalosome and neddylation in DNA damage signaling and repair. Biomolecules 2015, 5, 2388-2416. [CrossRef]

17. Gilberto, S.; Peter, M. Dynamic ubiquitin signaling in cell cycle regulation. J. Cell Biol. 2017, 216, 2259-2271. [CrossRef] [PubMed]

18. Zou, T.; Zhang, J. Diverse and pivotal roles of neddylation in metabolism and immunity. FEBS J. 2020. [CrossRef]

19. Zhou, L.; Jia, L. Targeting protein neddylation for cancer therapy. In Cullin-RING Ligases and Protein Neddylation; Sun, Y., Wei, W., Jin, J., Eds.; Springer: Berlin, Germany, 2020; Volume 1217, pp. 297-315. [CrossRef]

20. He, X.; Zhu, A.; Feng, J.; Wang, X. Role of neddylation in neurological development and diseases. Biotechnol. Appl. Biochem. 2021. [CrossRef] [PubMed]

21. Osaka, F.; Saeki, M.; Katayama, S.; Aida, N.; Toh, E.A.; Kominami, K.; Toda, T.; Suzuki, T.; Chiba, T.; Tanaka, K.; et al. Covalent modifier NEDD8 is essential for SCF ubiquitin-ligase in fission yeast. EMBO J. 2000, 19, 3475-3484. [CrossRef] [PubMed]

22. Tateishi, K.; Omata, M.; Tanaka, K.; Chiba, T. The NEDD8 system is essential for cell cycle progression and morphogenetic pathway in mice. J. Cell Biol. 2001, 155, 571-580. [CrossRef] 
23. Pereira, R.V.; Gomes, M.D.S.; Olmo, R.P.; Souza, D.M.; Jannotti-Passos, L.K.; Baba, E.H.; Castro-Borges, W.; Guerra-Sá, R. NEDD8 conjugation in Schistosoma mansoni: Genome analysis and expression profiles. Parasitol. Int. 2013, 62, 199-207. [CrossRef]

24. Meister, C.; Thieme, K.G.; Thieme, S.; Köhler, A.M.; Schmitt, K.; Valerius, O.; Braus, G.H. COP9 signalosome interaction with UspA/Usp15 deubiquitinase controls VeA-mediated fungal multicellular development. Biomolecules 2019, 9, 238. [CrossRef]

25. Mergner, J.; Kuster, B.; Schwechheimer, C. DENEDDYLASE1 protein counters automodification of neddylating enzymes to maintain NEDD8 protein homeostasis in Arabidopsis. J. Biol. Chem. 2017, 292, 3854-3865. [CrossRef] [PubMed]

26. Zhang, L.; Jing, H.; Li, H.; Chen, W.; Luo, B.; Zhang, H.; Dong, Z.; Li, L.; Su, H.; Xiong, W.-C.; et al. Neddylation is critical to cortical development by regulating Wnt/ $\beta$-catenin signaling. Proc. Natl. Acad. Sci. USA 2020, 117, 26448-26459. [CrossRef] [PubMed]

27. Kim, S.; Kwon, M.; Hwang, Y.; Yoon, J.; Park, S.; Kang, H.C. Stress-induced NEDDylation promotes cytosolic protein aggregation through HDAC6 in a p62-dependent manner. iScience 2021, 24, 102146. [CrossRef] [PubMed]

28. Romeralo, M.; Escalante, R.; Baldauf, S.L. Evolution and diversity of Dictyostelid social amoebae. Protist 2012, 163, 327-343. [CrossRef] [PubMed]

29. Mathavarajah, S.; Flores, A.; Huber, R.J. Dictyostelium discoideum: A model system for cell and developmental biology. Curr. Protoc. Essent. Lab. Tech. 2017, 15, 14.1.1-14.1.19. [CrossRef]

30. Fey, P.; Dodson, R.J.; Basu, S.; Hartline, E.C.; Chisholm, R.L. DictyBase and the Dicty Stock Center (version 2.0)—A progress report. Int. J. Dev. Biol. 2019, 63, 563-572. [CrossRef] [PubMed]

31. Sheikh, M.O.; Xu, Y.; van der Wel, H.; Walden, P.; Hartson, S.D.; West, C.M. Glycosylation of Skp1 promotes formation of Skp1-Cullin-1-F-box protein complexes in Dictyostelium. Mol. Cell. Proteom. 2015, 14, 66-80. [CrossRef]

32. Rosel, D.; Kimmel, A.R. The COP9 signalosome regulates cell proliferation of Dictyostelium discoideum. Eur. J. Cell Biol. 2006, 85, 1023-1034. [CrossRef]

33. Schwechheimer, C.; Serino, G.; Callis, J.; Crosby, W.L.; Lyapina, S.; Deshaies, R.J.; Gray, W.M.; Estelle, M.; Deng, X.W. Interactions of the COP9 signalosome with the E3 ubiquitin ligase SCFTIRI in mediating auxin response. Science 2001, 292, 1379-1382. [CrossRef]

34. Busch, S.; Eckert, S.E.; Krappmann, S.; Braus, G.H. The COP9 signalosome is an essential regulator of development in the filamentous fungus Aspergillus nidulans. Mol. Microbiol. 2004, 49, 717-730. [CrossRef] [PubMed]

35. Pintard, L.; Kurz, T.; Glaser, S.; Willis, J.H.; Peter, M.; Bowerman, B. Neddylation and deneddylation of CUL-3 is required to target MEI-1/katanin for degradation at the meiosis-to-mitosis transition in C. elegans. Curr. Biol. 2003, 13, 911-921. [CrossRef]

36. Doronkin, S.; Djagaeva, I.; Beckendorf, S.K. The COP9 signalosome promotes degradation of cyclin e during early drosophila oogenesis. Dev. Cell 2003, 4, 699-710. [CrossRef]

37. He, Q.; Cheng, P.; Liu, Y. The COP9 signalosome regulates the Neurospora circadian clock by controlling the stability of the SCFFWD-1 complex. Genes Dev. 2005, 19, 1518-1531. [CrossRef]

38. Wee, S.; Geyer, R.K.; Toda, T.; Wolf, D.A. CSN facilitates Cullin-RING ubiquitin ligase function by counteracting autocatalytic adapter instability. Nat. Cell Biol. 2005, 7, 387-391. [CrossRef]

39. Wu, J.-T.; Lin, H.-C.; Hu, Y.-C.; Chien, C.-T. Neddylation and deneddylation regulate Cul1 and Cul3 protein accumulation. Nat. Cell Biol. 2005, 7, 1014-1020. [CrossRef] [PubMed]

40. Cope, G.A.; Deshaies, R.J. Targeted silencing of Jab1/Csn5 in human cells downregulates SCF activity through reduction of F-box protein levels. BMC Biochem. 2006, 7, 1. [CrossRef]

41. Schmidt, M.W.; McQuary, P.R.; Wee, S.; Hofmann, K.; Wolf, D.A. F-box-directed CRL complex assembly and regulation by the CSN and CAND1. Mol. Cell 2009, 35, 586-597. [CrossRef]

42. Barth, E.; Hübler, R.; Baniahmad, A.; Marz, M. The evolution of COP9 signalosome in unicellular and multicellular organisms. Genome Biol. Evol. 2016, 8, 1279-1289. [CrossRef]

43. Heidel, A.J.; Lawal, H.M.; Felder, M.; Schilde, C.; Helps, N.R.; Tunggal, B.; Rivero, F.; John, U.; Schleicher, M.; Eichinger, L.; et al. Phylogeny-wide analysis of social amoeba genomes highlights ancient origins for complex intercellular communication. Genome Res. 2011, 21, 1882-1891. [CrossRef] [PubMed]

44. Brownell, J.E.; Sintchak, M.D.; Gavin, J.M.; Liao, H.; Bruzzese, F.J.; Bump, N.J.; Soucy, T.A.; Milhollen, M.A.; Yang, X.; Burkhardt, A.L.; et al. Substrate-assisted inhibition of ubiquitin-like protein-activating enzymes: The NEDD8 E1 inhibitor MLN4924 forms a NEDD8-AMP mimetic in situ. Mol. Cell 2010, 37, 102-111. [CrossRef] [PubMed]

45. Oladghaffari, M.; Islamian, J.P.; Baradaran, B.; Monfared, A.S. MLN4924 therapy as a novel approach in cancer treatment modalities. J. Chemother. 2016, 28. [CrossRef] [PubMed]

46. Aubry, A.; Yu, T.; Bremner, R. Preclinical studies reveal MLN4924 is a promising new retinoblastoma therapy. Cell Death Discov. 2020, 6, 1-12. [CrossRef]

47. Kim, K.; Pröbstel, A.-K.; Baumann, R.; Dyckow, J.; Landefeld, J.; Kogl, E.; Madireddy, L.; Loudermilk, R.; Eggers, E.L.; Singh, S.; et al. Cell type-specific transcriptomics identifies neddylation as a novel therapeutic target in multiple sclerosis. Brain 2020, 144, 450-461. [CrossRef] [PubMed]

48. Yao, J.; Liang, X.; Liu, Y.; Zheng, M. Neddylation: A versatile pathway takes on chronic liver diseases. Front. Med. $2020,7,586881$. [CrossRef] [PubMed] 
49. Ferris, J.; Espona-Fiedler, M.; Hamilton, C.; Holohan, C.; Crawford, N.; McIntyre, A.J.; Roberts, J.Z.; Wappett, M.; McDade, S.S.; Longley, D.B.; et al. Pevonedistat (MLN4924): Mechanism of cell death induction and therapeutic potential in colorectal cancer. Cell Death Discov. 2020, 6, 1-14. [CrossRef]

50. Fey, P.; Kowal, A.S.; Gaudet, P.; Pilcher, K.E.; Chisholm, R.L. Protocols for growth and development of Dictyostelium discoideum. Nat. Protoc. 2007, 2, 1307-1316. [CrossRef]

51. Jain, R.; Gomer, R. A developmentally regulated cell surface receptor for a density-sensing factor in Dictyostelium. J. Biol. Chem. 1994, 269, 9128-9136. [CrossRef]

52. McLaren, M.D.; Mathavarajah, S.; Kim, W.D.; Yap, S.Q.; Huber, R.J. Aberrant autophagy impacts growth and multicellular development in a Dictyostelium knockout model of CLN5 disease. Front Cell Dev. Biol. 2021. under review.

53. Schleicher, M.; Noegel, A.; Schwarz, T.; Wallraff, E.; Brink, M.; Faix, J.; Gerisch, G.; Isenberg, G. A Dictyostelium mutant with severe defects in alpha-actinin: Its characterization using cDNA probes and monoclonal antibodies. J. Cell Sci. 1988, 90, 59-71. [PubMed]

54. Huber, R.J.; Myre, M.A.; Cotman, S.L. Loss of Cln3 function in the social amoeba Dictyostelium discoideum causes pleiotropic effects that are rescued by human CLN3. PLoS ONE 2014, 9, e110544. [CrossRef]

55. Browning, D.D.; The, T.; O’Day, D.H. Comparative analysis of chemotaxis in Dictyostelium using a radial bioassay method: Protein tyrosine kinase activity is required for chemotaxis to folate but not to cAMP. Cell. Signal. 1995, 7, 481-489. [CrossRef]

56. Huber, R.J.; Mathavarajah, S. Secretion and function of $\mathrm{C} \ln 5$ during the early stages of Dictyostelium development. Biochim. Biophys. Acta BBA Mol. Cell Res. 2018, 1865, 1437-1450. [CrossRef] [PubMed]

57. Huber, R.J.; Myre, M.A.; Cotman, S.L. Aberrant adhesion impacts early development in a Dictyostelium model for juvenile neuronal ceroid lipofuscinosis. Cell Adhes. Migr. 2016, 11, 399-418. [CrossRef] [PubMed]

58. Laemmli, U.K. Cleavage of structural proteins during the assembly of the head of bacteriophage T4. Nat. Cell Biol. 1970, 227, 680-685. [CrossRef] [PubMed]

59. Kumar, S.; Stecher, G.; Li, M.; Knyaz, C.; Tamura, K.; Battistuzzi, F.U. MEGA X: Molecular evolutionary genetics analysis across computing platforms. Mol. Biol. Evol. 2018, 35, 1547-1549. [CrossRef] [PubMed]

60. Robert, X.; Gouet, P. Deciphering key features in protein structures with the new ENDscript server. Nucleic Acids Res. 2014, 42, W320-W324. [CrossRef]

61. Kelley, L.A.; Mezulis, S.; Yates, C.M.; Wass, M.N.; Sternberg, M.J.E. The Phyre2 web portal for protein modeling, prediction and analysis. Nat. Protoc. 2015, 10, 845-858. [CrossRef] [PubMed]

62. Souphron, J.; Waddell, M.B.; Paydar, A.; Tokgoz-Gromley, Z.; Roussel, M.F.; Schulman, B.A. Structural dissection of a gating mechanism preventing misactivation of ubiquitin by NEDD8's E1. Biochemistry 2008, 47, 8961-8969. [CrossRef] [PubMed]

63. Hotton, S.K.; Callis, J. Regulation of cullin RING ligases. Annu. Rev. Plant. Biol. 2008, 59, 467-489. [CrossRef] [PubMed]

64. Wada, H.; Kito, K.; Caskey, L.S.; Yeh, E.T.; Kamitani, T. Cleavage of the C-terminus of NEDD8 by UCH-L3. Biochem. Biophys. Res. Commun. 1998, 251, 688-692. [CrossRef]

65. Hakenjos, J.P.; Richter, R.; Dohmann, E.M.N.; Katsiarimpa, A.; Isono, E.; Schwechheimer, C. MLN4924 is an efficient inhibitor of NEDD8 conjugation in plants. Plant. Physiol. 2011, 156, 527-536. [CrossRef]

66. Malhab, L.J.B.; Descamps, S.; Delaval, B.; Xirodimas, D.P. The use of the NEDD8 inhibitor MLN4924 (Pevonedistat) in a cyclotherapy approach to protect wild-type p53 cells from MLN4924 induced toxicity. Sci. Rep. 2016, 6, 37775. [CrossRef] [PubMed]

67. Misra, M.; Kuhn, M.; Löbel, M.; An, H.; Statsyuk, A.V.; Sotriffer, C.; Schindelin, H. Dissecting the specificity of adenosyl sulfamate inhibitors targeting the ubiquitin-activating enzyme. Structure 2017, 25, 1120-1129. [CrossRef]

68. Rot, G.; Parikh, A.; Curk, T.; Kuspa, A.; Shaulsky, G.; Zupan, B. DictyExpress: A Dictyostelium discoideum gene expression database with an explorative data analysis web-based interface. BMC Bioinform. 2009, 10, 265. [CrossRef]

69. Echalier, A.; Pan, Y.; Birol, M.; Tavernier, N.; Pintard, L.; Hoh, F.; Ebel, C.; Galophe, N.; Claret, F.X.; Dumas, C. Insights into the regulation of the human COP9 signalosome catalytic subunit, CSN5/Jab1. Proc. Natl. Acad. Sci. USA 2013, 110, 1273-1278. [CrossRef]

70. Mohanty, S.; Lee, S.; Yadava, N.; Dealy, M.J.; Johnson, R.S.; Firtel, R.A. Regulated protein degradation controls PKA function and cell-type differentiation in Dictyostelium. Genes Dev. 2001, 15, 1435-1448. [CrossRef]

71. Yuen, I.S.; Taphouse, C.; Halfant, K.A.; Gomer, R.H. Regulation and processing of a secreted protein that mediates sensing of cell density in Dictyostelium. Development 1991, 113, 1375-1385.

72. Brar, S.K.; Siu, C.H. Characterization of the cell adhesion molecule gp24 in Dictyostelium discoideum. Mediation of cell-cell adhesion via a Ca ${ }^{2+}$-dependent mechanism. J. Biol. Chem. 1993, 268, 24902-24909. [CrossRef]

73. Wang, B.; Kuspa, A. CulB, a putative ubiquitin ligase subunit, regulates prestalk cell differentiation and morphogenesis in Dictyostelium spp. Eukaryot. Cell 2002, 1, 126-136. [CrossRef] [PubMed]

74. Kin, K.; Forbes, G.; Cassidy, A.; Schaap, P. Cell-type specific RNA-Seq reveals novel roles and regulatory programs for terminally differentiated Dictyostelium cells. BMC Genom. 2018, 19, 1-18. [CrossRef] [PubMed]

75. Jia, L.; Li, H.; Sun, Y. Induction of p21-dependent senescence by an NAE inhibitor, MLN4924, as a mechanism of growth suppression. Neoplasia 2011, 13, 561-569. [CrossRef] 
76. Chen, Y.; Du, M.; Yusuying, S.; Liu, W.; Tan, Y.; Xie, P. Nedd8-activating enzyme inhibitor MLN4924 (Pevonedistat), inhibits miR-1303 to suppress human breast cancer cell proliferation via targeting p27Kip1. Exp. Cell Res. 2020, 392, 112038. [CrossRef] [PubMed]

77. Zhou, X.; Han, S.; Wilder-Romans, K.; Sun, G.Y.; Zhu, H.; Liu, X.; Tan, M.; Wang, G.; Feng, F.Y.; Sun, Y. Neddylation inactivation represses androgen receptor transcription and inhibits growth, survival and invasion of prostate cancer cells. Neoplasia 2020, 22, 192-202. [CrossRef]

78. Liao, S.; Hu, H.; Wang, T.; Tu, X.; Li, Z. The protein neddylation pathway in Trypanosoma brucei: Functional characterization and substrate identification. J. Biol. Chem. 2017, 292, 1081-1091. [CrossRef] [PubMed]

79. Kuo, K.-L.; Ho, I.-L.; Shi, C.-S.; Wu, J.-T.; Lin, W.-C.; Tsai, Y.-C.; Chang, H.-C.; Chou, C.-T.; Hsu, C.-H.; Hsieh, J.-T.; et al. MLN4924, a novel protein neddylation inhibitor, suppresses proliferation and migration of human urothelial carcinoma: In vitro and in vivo studies. Cancer Lett. 2015, 363, 127-136. [CrossRef]

80. Lan, H.; Tang, Z.; Jin, H.; Sun, Y. Neddylation inhibitor MLN4924 suppresses growth and migration of human gastric cancer cells. Sci. Rep. 2016, 6, 24218. [CrossRef] [PubMed]

81. Tong, S.; Si, Y.; Yu, H.; Zhang, L.; Xie, P.; Jiang, W. MLN4924 (Pevonedistat), a protein neddylation inhibitor, suppresses proliferation and migration of human clear cell renal cell carcinoma. Sci. Rep. 2017, 7, 1-9. [CrossRef]

82. Sobko, A.; Ma, H.; Firtel, R.A. Regulated SUMOylation and ubiquitination of DdMEK1 is required for proper chemotaxis. Dev. Cell 2002, 2, 745-756. [CrossRef] 